\title{
MODEL SISTEM INFORMASI PEMBUKUAN UNTUK MONITORING TRANSAKSI KOPERASI DALAM MENDUKUNG PERHITUNGAN SISA HASIL USAHA
}

\author{
Deden Roni Nurjaman ${ }^{1}$, Turki Salim ${ }^{2}$, Risma Damayanti ${ }^{3}$ \\ Dosen Teknik Informatika STMIK Raharja ${ }^{1,2}$,Mahasiswa Sistem Informasi STMIK Raharja ${ }^{3}$ \\ Email:deden.roni@raharja.info ${ }^{1}$,turki@raharja.info ${ }^{2}$,risma@raharja.info ${ }^{3}$
}

\begin{abstract}
ABSTRAK
Koperasi berfungsi untuk membangun dan mengembangkan potensi kemampuan ekonomi anggota untuk meningkatkan kesejahteraan ekonomi dan sosial. Koperasi didirikan bertujuan untuk mewujudkan kesejahteraan anggota pada khususunya dan masyarakat pada umumnya serta ikut membangun tatanan perekonomian nasional dalam rangka mewujudkan masyarakat yang maju, adil dan makmur yang berlandaskan Pancasila dan Undang-Undang Dasar 1945. Koperasi menyelenggarakan beberapa jenis usaha seperti simpan pinjam, warung serba ada dan perdagangan umum. Dalam menjalankan usaha tersebut koperasi melakukan pembukuan untuk mengetahui laba/rugi koperasi serta besaran sisa hasil usaha yang adil dan sebanding dengan besarnya jasa usaha masing-masing anggota. Dalam proses pembukuan tersebut sering terjadi beberapa permasalahan seperti, tidak tercatatnya dengan baik setiap transaksi yang kecil dan rutin, adanya kesalahan perhitungan yang disebabkan human error, lambatnya proses perhitungan sisa hasil usaha yang menyebabkan tertundanya pembuatan laporan. Untuk mengatasi hal ini perlu dirancang suatu model sistem informasi pembukuan dalam bentuk use case diagram sebagai model rancangan dan class diagram sebagai model database serta aplikasi sistem sebagai bentuk implementasi, sehingga hal ini mampu menciptakan suatu sistem informasi pembukuan untuk monitoring transaksi koperasi dalam mendukung perhitungan sisa hasil usaha secara efektif, efisien, cepat dan akurat.
\end{abstract}

Kata kunci : monitoring transaksi, pembukuan koperasi, sisa hasil usaha

\begin{abstract}
Cooperatives function to build and develop the potential economic capacity of members to improve economic and social welfare. Cooperatives are established aiming to realize the welfare of members in particular and the community at large and participate in building the national economic order in order to create an advanced, just and prosperous society based on Pancasila and the 1945 Constitution. Cooperatives organize several types of businesses such as savings and loans, all-round shops there and general trade. In running the business, the cooperative conducts bookkeeping to find out the profit / loss of the cooperative and the amount of the remaining business results that are fair and comparable to the amount of business services of each member. In the bookkeeping process there were often several problems such as, not well recorded every small and routine transaction, there were miscalculation caused by human error, the slow process of calculating the remaining business results which caused delays in making the report. To overcome this, it is necessary to design a bookkeeping information system model in the form of use case diagrams as a design model and class diagram as a database model and system application as a form of implementation, so that it is able to create a bookkeeping information system for monitoring cooperative transactions in supporting the calculation of the remaining results business effectively, efficiently, quickly and accurately.
\end{abstract}


Keywords: transaction monitoring, cooperative bookkeeping, operating results

\section{PENDAHULUAN}

Koperasi merupakan badan hukum yang didirikan oleh orang perseorangan atau badan hukum koperasi, dengan pemisahan kekayaan para anggotanya sebagai modal untuk menjalankan usaha yang memenuhi aspirasi dan kebutuhan bersama di bidang ekonomi, sosial, dan budaya [1]. Koperasi sebagai organisasi otonom dari orang -orang yang berhimpun secara sukarela untuk memenuhi kebutuhan dan aspirasi ekonomi secara bersama-sama melalui kegiatan usaha yang dimiliki dan dikendalikan secara demokratis [9]. Monitoring transaksi dilakukan untuk mengkaji ketepatan setiap peristiwa terjadinya aktivitas keuangan pada koperasi sehingga apabila terdapat masalah dapat langsung diatasi. Sisa hasil usaha koperasi adalah pendapatan koperasi yang diperoleh dalam satu tahun buku dikurang dengan biaya, penyusutan, dan kewajiban lain termasuk pajak dalam tahun buku yang bersangkutan [12]

Suatu sistem yang terotomatisasi dapat membantu petugas dalam menyelesaikan kewajibanya dangan lebih cepat sehingga mengurangi tingkat keterlambatan yang akan mengganggu stabilitas perusahaan. [5] Pembayaran adalah pelunasan utang oleh debitur kepada kreditur bisa dilakukan dalam bentuk uang atau barang. [2] Hutang pembelian merupakan tagihan yang ditagihkan oleh supplier atas pemesanan barang yang telah dilakukan sebelumnya berdasakan purchase order. Biasanya masa waktu pembayaran memliki jatuh tempo yang diberikan cukup bervrian yaitu pembayaran cash dan maksimal 30 hari.

\section{METODE PENELITIAN}

Untuk mendapatkan data yang diperlukan agar mampu merancang sistem ini dengan baik peneliti melakukan beberapa langkah metode penelitian.

\section{Metode Pengumpulan Data}

Metode wawancara (interview), metode ini dilakukan melaui proses tanya jawab dengan seseorang atau beberapa narasumber di tempat atau lokasi dimana objek penelitian dilakukan.

Metode pengamatan (observasi), metode pengumpulan data melalui pengamatan langsung atau peninjauan secara cermat dan langsung di lapangan atau lokasi penelitian.

Study pustaka (literature review), metode untuk mendapatkan informasi dan data dari beberapa sumber atau buku yang diperlukan untuk kebutuhan penganalisaan dan percangan sistem baru yang diusulkan.

\section{Metode Analisa}

Metode analisa PIECES (Performance, Information, Economy, Control/Security, Efficiency, Service) yang bertujuan untuk menganalisa sistem yang berjalan dari segi kinerja dan keamanan apakah informasi yang dihasilkan sudah efektif \& efisien sehingga dapat memberikan pelayanan yang baik.

\section{Metode Perancangan}

Proses perancangan sistem meliputi pembuatan model dengan menggunakan $U M L$ (Unified Modeling Language) : Use Case Diagram, Sequence Diagram, Activity Diagram, dan Class Diagram.

\section{Metode Testing}


Dalam proses pengujian sistem pembukuan menggunakan Blackbox Testing . metode ini digunakan untuk menemukan kesalahan dalam beberapa kategori, antara lain : fungsi fungsi yang hilang, kesalahan tampilan luar, kesalahan output, kesalahan dalam struktur data dan kesalahan performa.

\section{PERMASALAHAN}

Koperasi berfungsi mengembangkan potensi kemampuan ekonomi anggota untuk meningkatkan kesejahteraan ekonomi dan sosial. Koperasi menyelenggarakan beberapa jenis usaha seperti simpan pinjam, warung serba ada dan perdagangan umum. Dalam menjalankan usaha ini koperasi melakukan pembukuan untuk mengetahui laba/rugi serta besaran sisa hasil usaha yang adil dan sebanding dengan besarnya jasa usaha masing-masing anggota. pada saat proses pembukuan sering terjadi masalah seperti tidak tercatatnya dengan baik setiap transaksi yang kecil dan rutin, adanya kesalahan perhitungan yang disebabkan human error, lambatnya proses perhitungan sisa hasil usaha yang menyebabkan tertundanya pembuatan laporan.

\section{LITERATURE}

Penelitian yang dilakukan oleh I Gusti Made Karmawan dalam jurnal ComTech Vol.5 No. 2 Desember 2014, dengan judul "Perancangan Sistem Informasi Serba Usaha Pada Koperasi Tangerang". Dalam penelitian ini,bertujuan untuk meganalisa masalah-masalah yang mungkin terjadi pada sistem penjualan dan penerimaan kas sehingga dapat memperbaiki masalahmasalah yang ada. Hasil dari penelitian ini, sistem yang sedang berjalan masih melakukan pencatatan secara manual, sehingga berpengaruh pada efisiensi waktu dan tenaga. Keamanan dan pengolahan data juga diragukan kebenarannya karena tidak ada kemungkinan kecurangan yang disengaja maupun yang tidak disengaja.

Penelitian yang dilakukan oleh Farokhah Muzayinatun Niswah dalam jurnal ekonomi syariah teori dan terapan vol. 4 no. 12 desember 2017, dengan judul " faktor yang mempengaruhi kenaikan dan penurunan Sisa Hasil Usaha (SHU) koperasi syariah". Dalam penelitian ini, dibahas tentang pengaruh modal sendiri, aset dan pendapatan pembiayan terhadap pembagian sisa hasil usaha koperasi syariah. Hasil dari penelitian ini, modal sendiri dan aset tidak berpengaruh signifikan secara persial terhadap sisa hasil usaha, sedangkan pendapatan pembiayaan berpengaruh signifikan secara parsial terhadap sisa hasil usaha. 


\section{HASIL DAN PEMBAHASAN}

\section{Usecase Diagram}

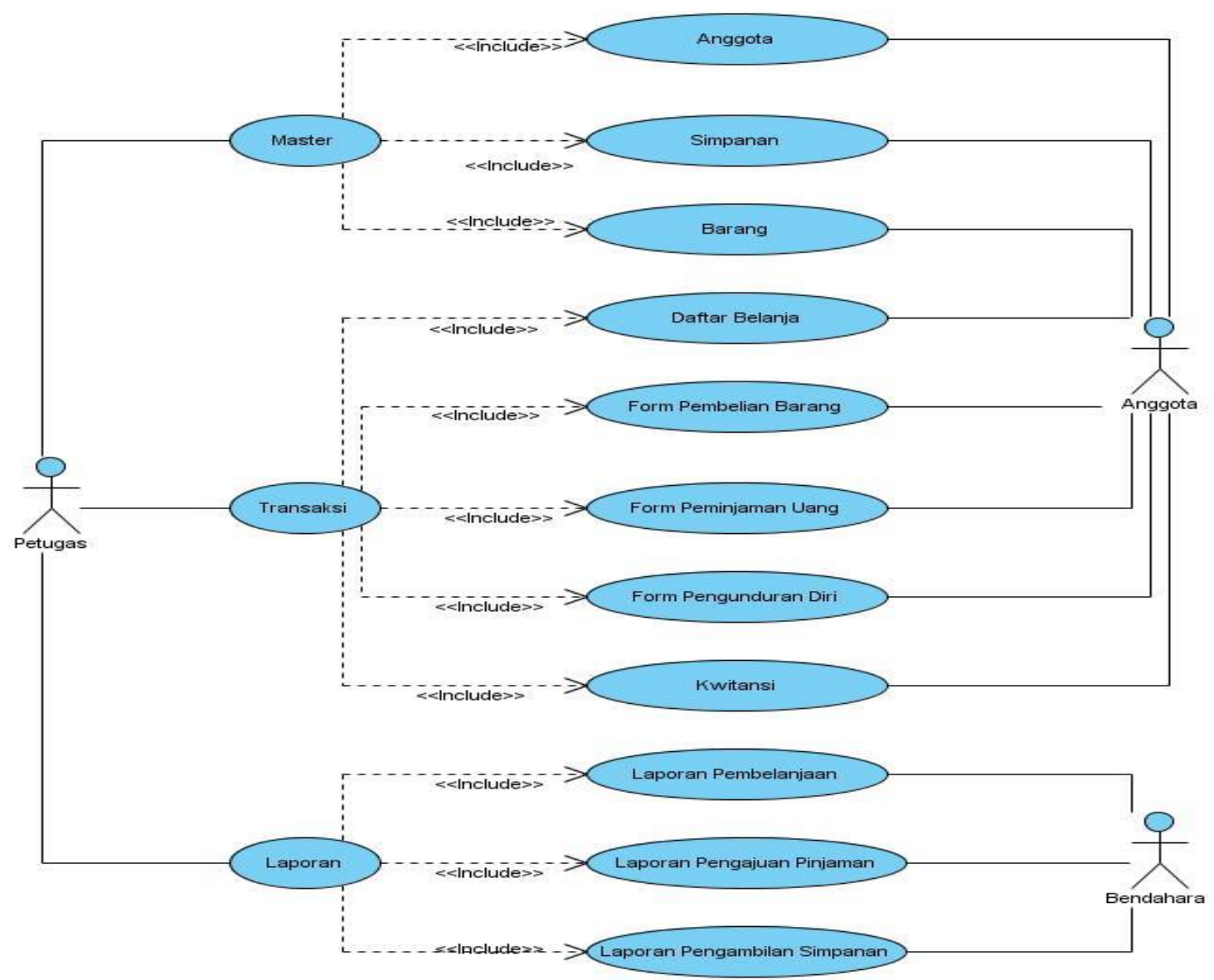

Gambar 1. Usecase Diagram Usulan

Terlihat dalam usecase diagram (gambar 1), terdapat 3 (tiga) actor yaitu : petugas, anggota, bendahara dan terdapat 3 (tiga) usecase utama yaitu : master, transaksi, laporan. Dimana pada usecase master terdapat 3 (tiga) sub usecase yaitu : anggota, simpanan, barang. Pada usecase transaksi terdapat 5 (lima) sub usecase yaitu : daftar belanja, form pembelian barang, form peminjaman uang, form pengunduran diri, kwitansi. Pada usecase laporan terdapat 3 (tiga) sub usecase yaitu : laporan pembelanjaan, laporan pengajuan pinjaman, laporan pengambilan simpanan.

Fungsi actor dalam usecase diagaram (gambar 1) yaitu : petugas berfungsi mencatat anggota, simpanan dan jumlah barang, lalu mendata setiap transaksi daftar belanja, pembelian barang, peminjaman uang, pengunduran diri anggota dan membuat kwitansi. petugas juga membuat laporan pembelanjaan, laporan pengajuan pinjaman dan laporan pengambilan simpanan yang akan diserahkan ke bendahara. Anggota berfungsi untuk memberikan data diri sebagai anggota, membayar iuran simpanan, melakukan transaksi belanja, pembelian barang, peminjaman uang ataupun mengundurkan diri sebagai anggota dan berhak untuk mendapatkan kwitansi dari setiap transaksi yang dilakukan. Bendahara berfungsi untuk menerima laporan pembelanjaan, laporan pinjaman dan laporan pengambilan simpanan dari petugas yang menjadi dasar untuk perhitungan sisa hasil usaha. 


\section{Class Diagram}

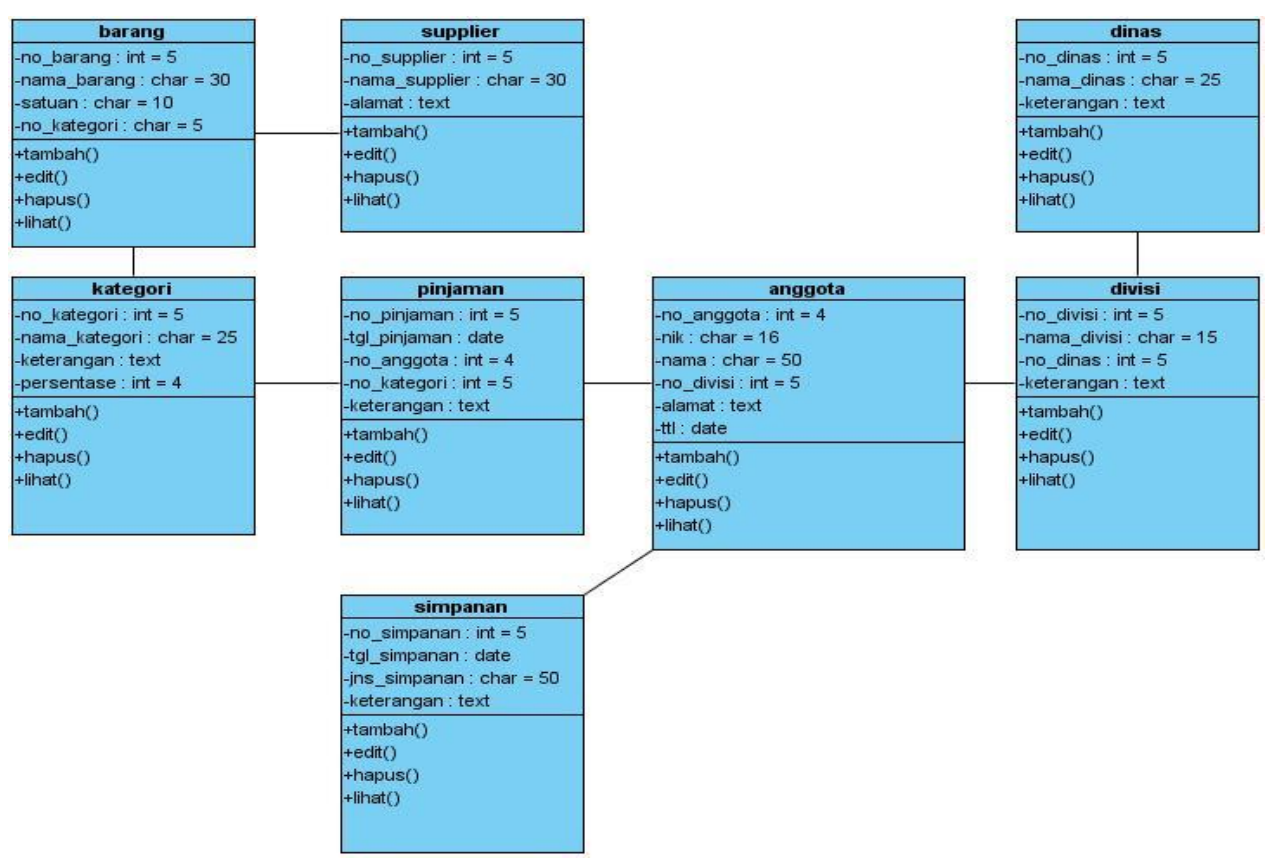

Gambar 2. Class Diagram Usulan

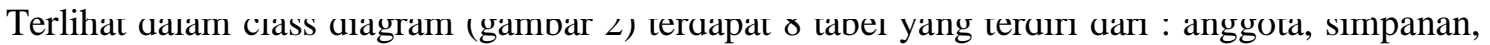
pinjaman,kategori, divisi, dinas, supplier, barang. Yang dimana masing-masing tabel terdapat atribute pada tabel anggota terdapat atribut nomor anggota, nama anggota, nik, nomor divisi, alamat dan tempat tanggal lahir dengan operasi tambah, lihat, edit, hapus. Pada tabel simpanan terdapat atribute nomor simpanan, tanggal simpanan, jenis simpanan dan keterangan dengan operasi tambah, edit, lihat, hapus. Pada tabel pinjaman terdapat atribute nomor pinjaman, tanggal pinjaman, nomor anggota, nomor kategori dan keterangan dengan operasi tambah,lihat,edit dan hapus. Pada tabel kategori terdapat atribute nomor kategori, nama kategori, keterangan dan persentase dengan operasi tambah, edit, lihat, hapus. Pada tabel divisi terdapat atribute nomor divisi, nama divisi, nomor dinas dan keterangan dengan operasi tambah,hapus,lihat dan edit. Pada tabel dinas terdapat atribute nomor dinas, nama dinas dan keterangan dengan operasi tambah, lihat, edit dan hapus. Pada tabel supplier terdapat atribute nomor supplier, nama supplier dan alamat dengan operasi tambah, lihat, hapus, edit. Pada tabel barang terdapat atribute nomor barang, nama barang, satuan dan nomor kategori dengan operasi tambah, edit, hapus dan lihat .

\section{IMPLEMENTASI}

Rancangan aplikasi sistem informasi pembukuan koperasi, penulis membuat aplikasi yang sesuai dengan kebutuhan administrator koperasi untuk pembuatan laporan, berikut model rancangan yang dibuat :

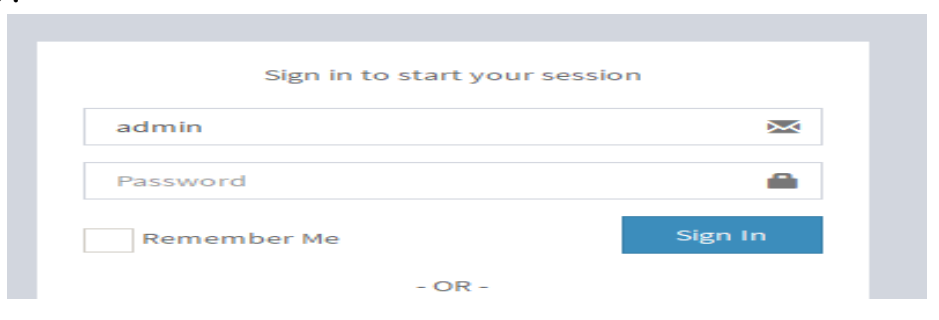

Gambar 3. Tampilan menu Login 
Tampilan diatas (gambar 3) merupakan tampilan menu login yang digunakan administrator untuk membuka aplikasi pembukuan dengan mengisi kolom username dengan admin dan password.

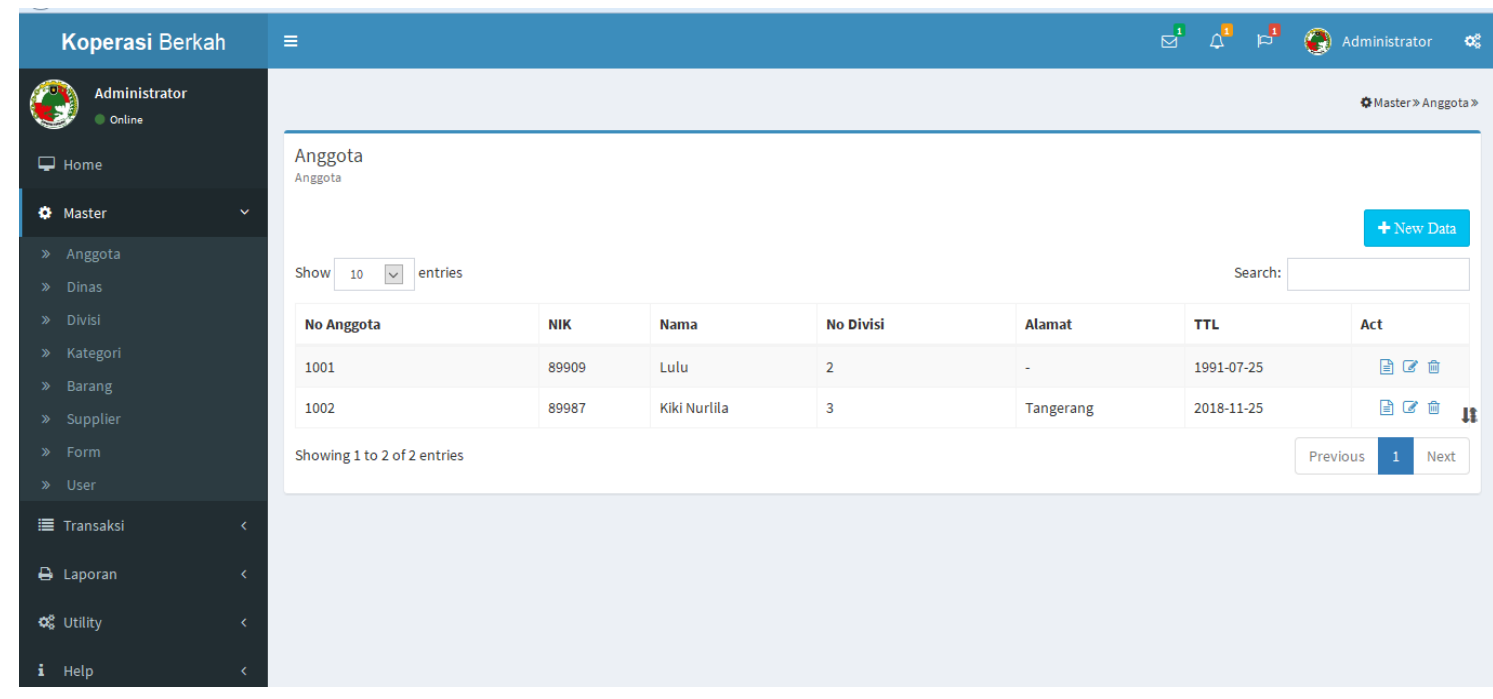

Tampilan diatas (gambc Gambar 4. Tampilan menu anggota

rat informasi no anggota, nik, nanla, IIU uıvısı, alanlal, ul uanl acı unIlanla verıungsi untuk mengedit,menghapus dan melihat data anggota.

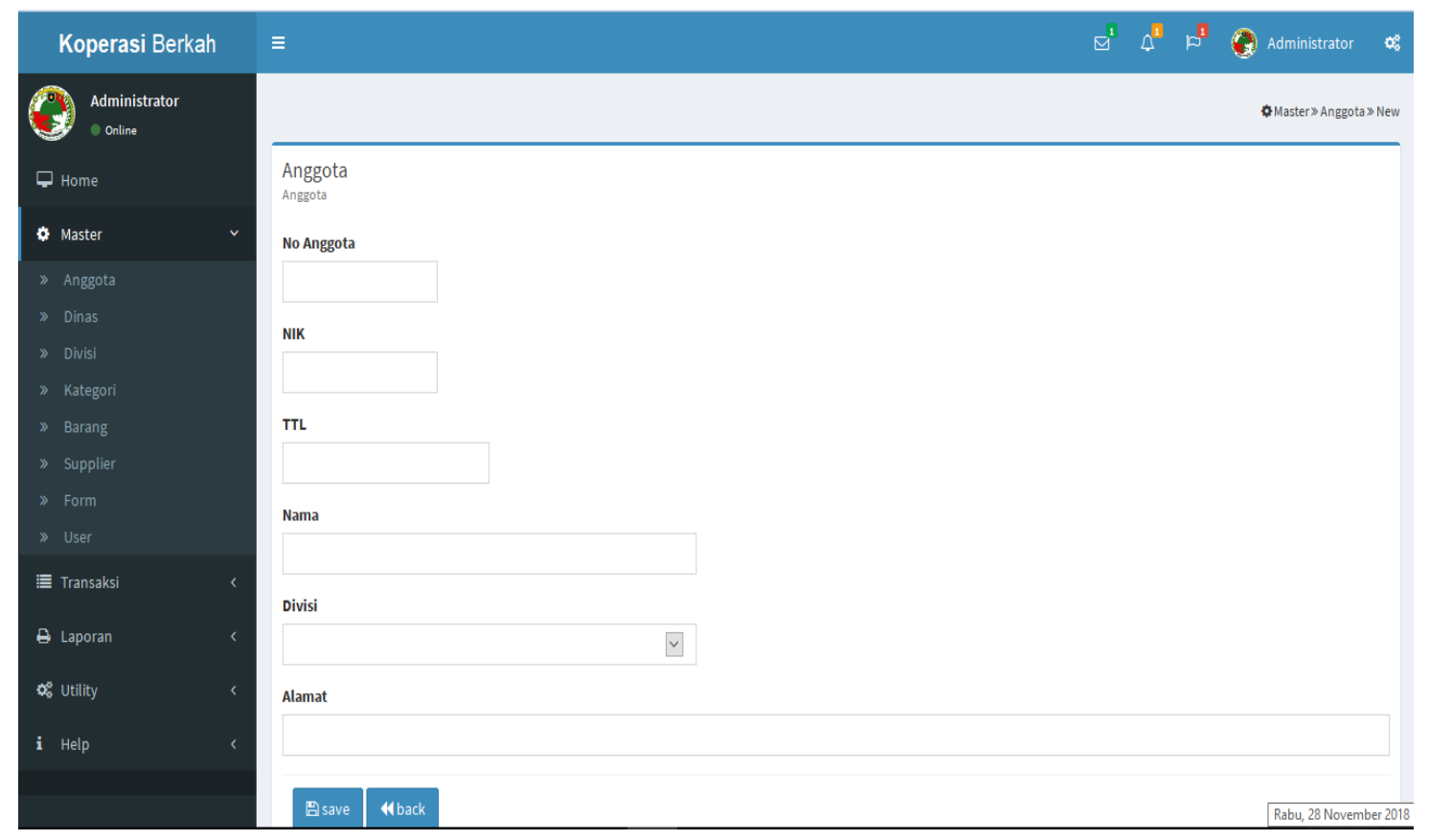

Tampilan diatas Gambar 5 . Tampilan menu input anggota baru gunakan untuk memasukan datc dan alamat. 


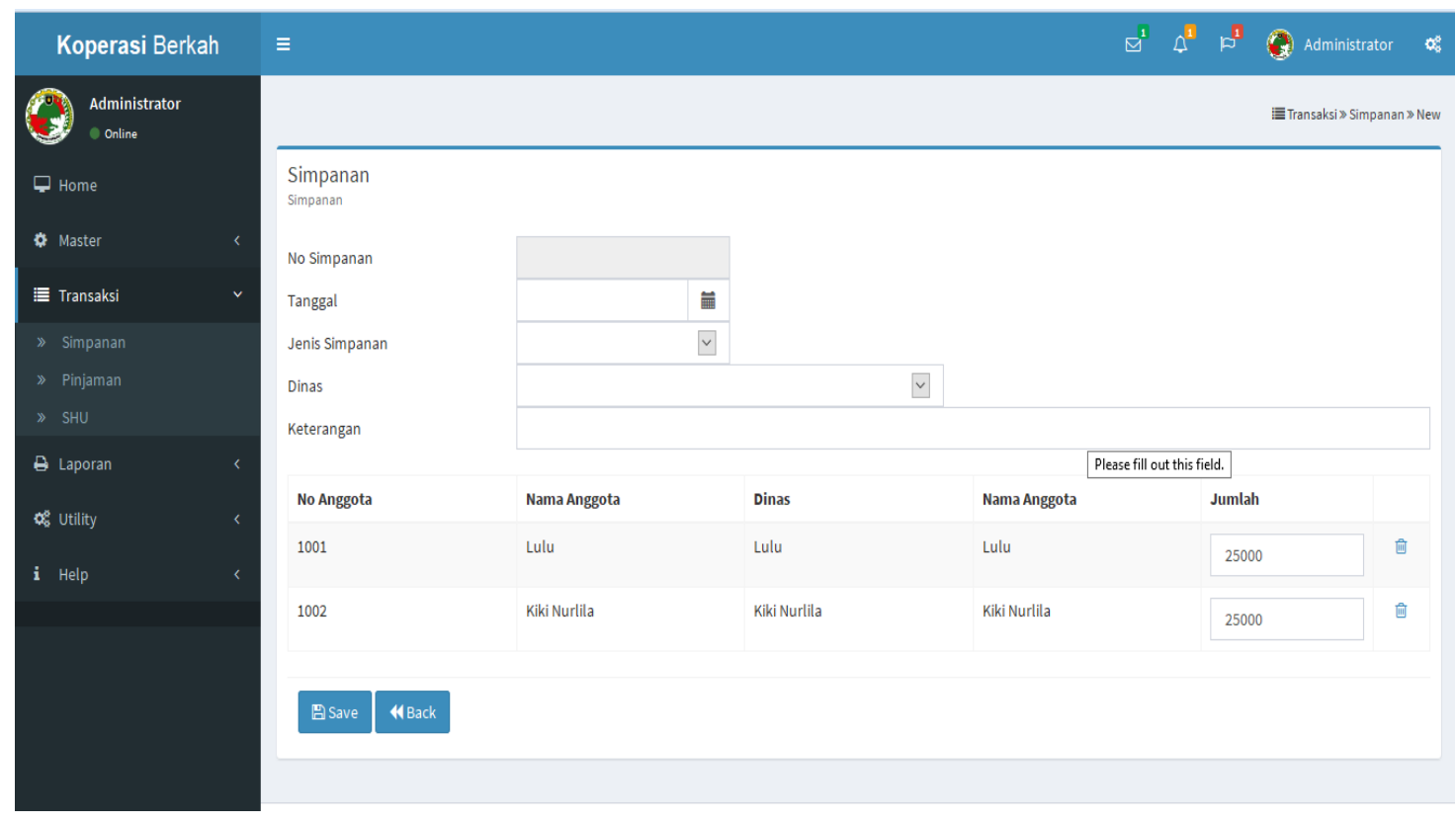

Gambar 6. Tampilan menu input simpanan anggota

Tampilan diatas (gambar 6) merupakan tampilan menu input simpanan anggota dengan memasukkan data tanggal simpanan,jenis simpanan, asal dinas dan keterangan .

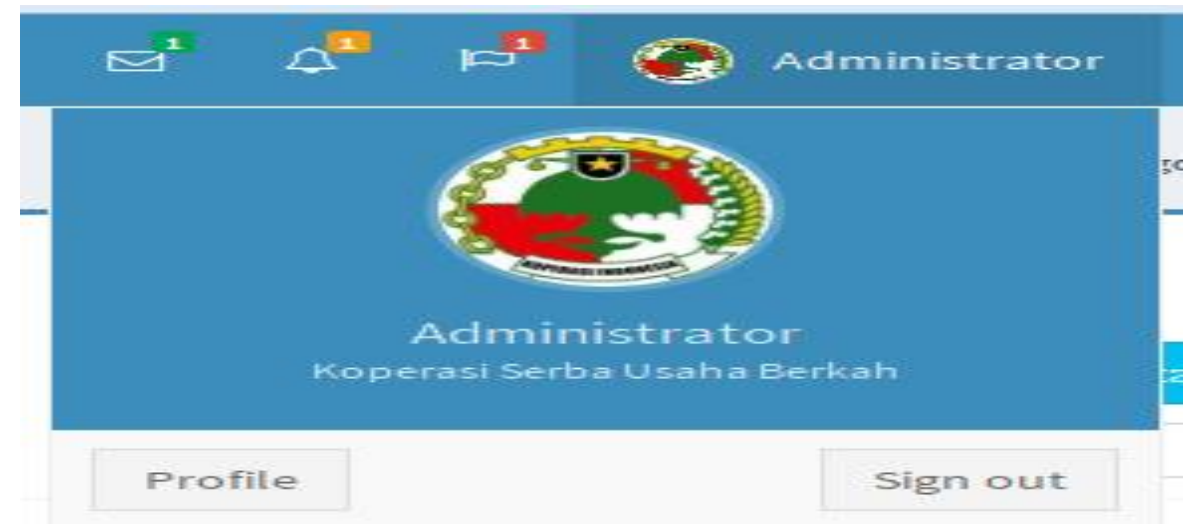

\section{Gambar 7. Tampilan menu administrator}

Tampilan diatas (gambar 7) merupakan tampilan menu adminitrator yang berisi nama koperasi menu profile dan tombol sign out untuk keluar dari aplikasi.

\section{KESIMPULAN}

Dapat disimpulkan bahwa sistem informasi pembukuan koperasi mampu mempermudah administrator untuk melakukan pembukuan setiap transaksi yang terjadi di koperasi. Dengan adanya sistem informasi ini administrator dapat lebih cepat dalam membuat laporan harian,bulanan maupun tahunan yang akan di jadikan dasar dalam perhitungan dan pembagian sisa hasil usaha anggota koperasi. 


\section{DAFTAR PUSTAKA}

[1] Tunggal, Hadi Setia. 2013. Undang - Undang Perkoperasian. Jakarta : Harvarindo

[2] Junaidi, Junaidi, Abdul Roji, and Kharis Munawar. "Konsep Otomatisasi Sistem Pembayaran SPP Online Untuk Mengurangi Tingkat Keterlambatan." Proceedings Konferensi Nasional Sistem dan Informatika (KNS\&I) (2015).

[3] Rijan, Yunirman, and Ira Koesoemawati. "Cara Mudah Membuat Surat Perjanjian/Kontrak dan Surat Penting Lainnya." Raih Asa Sukses, Depok (2009).

[4] Junaidi, Junaidi, Ladyca Anugrah, and Adhitya Dwi Pancasakti. "Model Aplikasi Monitoring Sistem Absensi Sidik Jari Sebagai Pendukung Keputusan Untuk Penilaian Kinerja Pegawai." Proceedings Konferensi Nasional Sistem dan Informatika (KNS\&I) (2015).

[5] Sugianto. 2013. "Perancangan Sistem Informasi Penjualan Pada Butik Luwes Fashion Kecamatan Tulakan." Indonesian Jurnal on Computer Science-Speed (IJCSS) Vol 2 No 1 ISSN:2302-1136 (2013).

[6] Junaidi, Junaidi, Abdul Roji, and Kharis Munawar. "Konsep Otomatisasi Sistem Pembayaran SPP Online Untuk Mengurangi Tingkat Keterlambatan." Proceedings Konferensi Nasional Sistem dan Informatika (KNS\&I) (2015).

[7] Henderi, Henderi, Junaidi Junaidi, and Tubagus Ahmad Harja Kusuma. "Dashboard Monitoring System Penjualan Dan Reward Mobile Kios PT. Telekomunikasi Seluler." Semantik 2.1 (2012).

[8] Junaidi, Junaidi, Ridwan Arifin, and Amanda Septiani. "Rancang Bangun Aplikasi Sistem Inventory Berbasis Desktop Menggunakan JSE." Proceedings Konferensi Nasional Sistem dan Informatika (KNS\&I) (2015).

[9] Hendar. 2013. Manajemen Perusahaan Koperasi. Jakarta : Erlangga

[10] Junaidi, Junaidi, Novi Cholisoh, and Nur Hasanah. "Rancang Bangun Sistem Manajemen Aset IT Untuk Pencatatan History Maintenance Sebagai Pendukung Keputusan." SENSI Journal 4.2 (2018): 220-231.

[11] Junaidi, Junaidi, Retno Setianingsih, and Khusnul Khotimah. "Rancang Bangun Sistem Penerimaan Dan Pengeluaran Barang Menggunakan Java Aplikasi." Proceedings Konferensi Nasional Sistem dan Informatika (KNS\&I) (2015).

[12] Undang- Undang Dasar 1945. No.25/1992. Tentang Perkoperasian :Republik Indonesia

[13] Junaidi, Junaidi, Sugeng Santoso, and Lusyani Sunarya. "Rekayasa Teknik Pemrograman Pencegahan Dan Perlindungan Dari Virus Lokal Menggunakan API Visual Basic." CCIT Journal 1.2 (2008): 134-153. 